\title{
ИССЛЕДОВАНИЕ РАСПРОСТРАНЕНИЯ ПРОДУКТОВ КОРРОЗИИ В ЖЕЛЕЗОБЕТОННЫХ КОНСТРУКЦИЯХ ПРИ ПОМОЩИ СПЕКТРАЛЬНЫХ МЕТОДОВ АНАЛИЗА
}

Кузнецов А.А., Волкова Н.В., Шарапова Я.В.

ФГБОУ ВО «Омский государственный университет путей сообщения», Омск, Россия wolf.volkova@yandex.ru

DOI: 10.26902/ASFE-11_165

Контактная сеть является важной частью комплекса электрифицированной железной дороги, работающая в тяжелых климатических и эксплуатационных условиях. Основной причиной снижения прочностных характеристик железобетонных опор контактной сети является коррозия стальной арматуры в данных опорах. Она подвергается воздействию агрессивных сред, таких как хлориды, сульфаты, нитраты и другие соли, а также воздействию перепадов температуры окружающей среды, осадков, токов утечки, нагревания проводов и т.д. [1].

Надежность контактной сети не имеет резерва, и потому к ней предъявляются высокие требования, в том числе к основному элементу - опоре. Падение опор вызывает обрыв проводов контактной сети, что вызывает нарушение режима движения поездов и может стать причиной человеческих жертв [2]. Поэтому контроль железобетонных конструкций является актуальной задачей современности.

В настоящее время наблюдение за коррозионной агрессивностью среды используется только в качестве общей профилактической меры [3]. Учитываются данные об изменении агрессивности атмосферы, грунтов и грунтовых вод, о наличии блуждающих токов и их величине. Дополнительная оценка проводится при видимых изменениях среды, например, повышения уровня грунтовых вод или засоления грунтов, и при обнаружении коррозионных повреждений бетона опор и фундаментов.

Для арматурных стержней в бетоне опасными веществами, вызывающими коррозию, являются ионы хлора, т.к. они разрушают пассивную пленку арматуры. Накопление хлористого натрия в порах бетона приводит к его разрушению. Таким образом, наличие хлоридов связано с процессом развития коррозии и потому их концентрации стоит уделять должное внимание.

Для определения концентрации хлора необходим метод, не требующий забора проб для работы в полевых условиях. Таким методом может стать лазерная искровая эмиссионная спектрометрия (LIBS - Laser-Induced Breakdown Spectroscopy). Данный метод обладает высокой чувствительностью и с высокой точностью определяет изменение концентрации веществ в железобетонных конструкциях.

Приводятся результаты экспериментальных исследований распределения концентраций продуктов коррозии, выделившихся на поверхности бетона. Дано описание образцов для градуирования приборов спектрального анализа, а также эксперименты на образцах с различной степенью коррозии. Исследована зависимость порогового значения концентрации продуктов коррозии $\left(\mathrm{C}_{\text {пор }}\right)$ на поверхности с уменьшением поперечного сечения арматуры, что является показателем её дефектности.

\section{Список литературы}

1. Алексеев С. Н. Долговечность железобетона в агрессивных средах. / С. Н. Алексеев, Ф. М. Иванов, С. Модры, П. Шиссль - М.: Стройиздат, 1990. - 320 с.

2. Подольский В.И. Железобетонные опоры контактной сети. Конструкция, эксплуатация, диагностика. - М.: Интекст, 1996. - 120 с.

3. Вазем И. В., Пономарев А. В. Анализ существующих методов диагностирования коррозионного состояния железобетонных опор контактной сети // материалы второй врерос. научн.-техн. конф. с междунар. участ. «Приборы и методы измерений, контроля качества и диагностики в промышленности и на транспорте» // Омский гос. ун-т пут. сообщен. 2016. С. 220-225. 